\title{
EM DEFESA DE CRÁTILO
}

\author{
ANTONIO MEDINA RODRIGUES* \\ Faculdade de Filosofia, Letras e Ciências Humanas \\ da Universidade de São Paulo
}

\begin{abstract}
RESUMO: Oobjetivo deste artigo é tentar uma interpretação das idéias de Crátilo relativas à essência da linguagem, principalmente daquelas que se podem inferir das recusas de Crátilo às proposições de Sócrates.
\end{abstract}

PALAVRAS-CHAVE: inferência; Heráclito; semelhança; Sócrates; silogismo; condicional; modus ponens.

SÓCRATES: Diz-me, porém, uma coisa: que potencial vêm a ter as palavras, e em que poderemos dizer que são positivas?

CRÁTILO: No fato de ensinarem, me parece, ó Sócrates, e tal coisa é simples, pois quem conhece as palavras também conhece as coisas.

SÓ.: O que dizes, Crátilo, seria mais ou menos isto: depois que alguém fique sabendo o que vem a ser um dado nome - para o qual existe uma coisa - certamente irá conhecer tal coisa, dado que ela se pareça ao nome, e uma arte, portanto, tem de haver, aquela mediante a qual todas as coisas mantenham semelhanças. É o que tu me pareces dizer, com dizeres que quem conhecer os nomes também conhece as coisas.

CR.: É certíssimo o que afirmas.

SÓ.: Espera um pouco, então vejamos qual vem a ser esse teor do ensinamento das coisas de que estás falando, e se por ventura um outro existe, que se mostre superior, ou se não existe um outro que não seja esse mesmo. Como te parece?

CRATILO: Não apenas creio não existir nenhum outro, como creio que esse é o excelente e o único. (Crátilo $435 \mathrm{~d}-436$ a)

SÓ.: Um momento, por Zeus! Não tínhamos nós concordado, e por mais de uma vez, que os nomes, quando bem formados, neces- 
sariamente se parecem às coisas que designam, sendo as imagens delas mesmas?

CR.: Sim.

SÓ.: Se é possível, portanto, a partir dos nomes, conseguir o pleno conhecimento das coisas, e realizar o mesmo partindo das coisas, qual dessas formas de conhecimento será a mais bela e a mais apropriada? Deve-se partir da imagem, e estudá-la por si mesma, para vermos se ela é boa e reproduz exatamente aquilo de que fala? $\mathrm{Ou}$, ao contrário, devemos partir da verdade, e a verificarmos por si própria e só depois aferirmos se ela foi corretamente expressada em imagens?

CR.: Deve-se obrigatoriamente partir da verdade. É o que me parece. (Crátilo 439 a)

Essas duas passagens, do Crátilo platônico, têm suficiente matéria para discussão de um tema capital nesse diálogo. Estão aí alguns sintomas, que nos orientam quanto à pendência de Crátilo e Sócrates, relativos sobretudo à doutrina do primeiro, sobre a qual, mais uma vez e sempre, ainda pairam dúvidas. Discutiremos a questão da semelhança. Esse, afinal, é um diálogo polêmico, nos personagens como na matéria. Daí ter sido ele objeto e fundamento de tantas discussões, recentes inclusive, sobre a natureza da linguagem, e com as quais está ligado o seu destino, no espírito e na concepção ${ }^{1}$. $O$ caráter polêmico vem das teses confrontadas (de Sócrates, Crátilo, Hermógenes) e de uma evidente tropelia, ou equivocação arquitetônica, idealizada por Platão, e que lhe dá o teor bem humorado, próximo da economia cômica, como lembra Robin². Faz parte dessa economia a postura silenciosa de Crátilo, tolerante o suficiente para aprovar aquilo que jamais aceitaria, tal como quando Sócrates lhe diz que existiria uma arte das semelhanças, e que seria nesta que ele, Crátilo, estaria pensando ("uma arte, portanto, tem de haver, aquela mediante a qual todas as coisas mantenham semelhanças"). A inferência era abusiva. Pois era no contrário que Crátilo pensava, e isto só poderíamos ver depois, a saber, que as semelhanças, vistas por ele, não implicariam uma arte, ainda que toda arte implique semelhanças ${ }^{3}$. Esse, portanto, é nosso tema.

Momentos assim, beirando o qüiproquó, são provocados, são fruto de uma arquitetura cênica, e não apenas filosófica. Duas ordens de semelhança são confundidas, a julgar pelo que encenam Sócrates e Crátilo. Para Sócrates as semelhanças são o que são para nós a olho nu: são visíveis como tais, podem 
ocorrer entre a palavra e a palavra, entre uma palavra e uma idéia, ou, para tocar num dos núcleos do platonismo, podem ocorrer entre uma coisa e sua idéia, que transcende a essa coisa. Tais são semelhanças instituídas pelo pensamento analítico ou pelo olhar inteligente. Por isso é que Sócrates precisa da idéia de um nomoteta, de alguém que engendre as palavras de acordo com um modelo e uma ciência (388 e: nomothétes, demioûrgos onomáton; 390 d-e). Mas, como há evidentemente palavras que não se parecem às coisas que representam, ele evocará também os erros e os acertos testemunhados no uso, e isto seria problema para a intervenção do dialético, aquele que usa e que discute o sentido que deve ser o real nas palavras. Quanto a Crátilo, porém, as semelhanças verdadeiras não são as que se verificam, mas as que são postuladas, as que existem por princípio, ao arrepio de qualquer prévia teorização. Para Crátilo, a questão seria o que hoje denominaríamos apodítica: quem conhece as palavras também conhece as coisas. Isso, que não é claro, é taxativo. Crátilo pressupõe que as coisas e as palavras se relacionem diretamente, e que uma semelhança deva aí estar implicada, por obrigação, ou necessidade interna, pois alguma semelhança deve haver, rebelde ou primitiva, para garantir a mesmidade entre as coisas e as palavras. Tal acoplamento, aceito postularmente, é que demonstraria a semelhança, e não o contrário, como queria Sócrates. O silêncio de Crátilo, nesse caso, não parece ter outra alternativa. Por vezes, ele parecerá assumir a figura do tonto, do incapacitado, do bomolókhos. E, de fato, como explicar semelhanças invisíveis, como quisera Heráclito (fr. 54: harmoníe aphanès phanerês kreítton)? Elas desapareceriam a partir da explicação. Como nas águas de Heráclito, elas existiriam uma vez apenas. Não se poderia objetivá-las. Daí que Crátilo se reduza à inefabilidade. Sócrates o "resume", fala no lugar dele, e "analisa" seu silêncio, é ver o texto acima.

A comédia, portanto, vai tirando proveito dos percalços filosóficos, vai dando tempo a si mesma. Crátilo, por seu silêncio, comprova a objeção de Sócrates a Heráclito: não podemos conhecer o que se altera sem parar. Essa tese, aparentemente poderosa, não poderia ser levada a sério por Platão. A época em que escrevera o diálogo, Platão andava impressionado por Heráclito, cuja doutrina "fluvial" lhe parecia boa à explicação do que é sensível. Tal é mais uma confusão proposital, ainda que preciosa ao gozo da leitura. E é possível que, dada sua natureza corretiva, o humor haja feito mais para a inteligência do que a própria sisudez.

Assim, por não se esclarecerem suficientemente as premissas (artifícios do humor, para render seus efeitos), as deduções se vão atropelando. O tema irrompera sem preparações, e pensa-se "na hora" sobre as questões, que se acumulam. E algumas coisas são evidentemente provocativas. "Teu nome não é 
Hermógenes" - diz Crátilo com impaciência - "ainda que todo o mundo te chamasse assim". Providencial foi que Crátilo não explicasse a Hermógenes as razões por que o tratava assim. Sócrates, para socorrer a este, reinicia a discussão: "Talvez ele pense que tu hajas fracassado nas tentativas de enriquecer" (Hermes é o deus da riqueza). E por aí vai.

A diferença do Crátilo, em relação a outros diálogos, é que, nestes, toda argumentação técnica é de certa forma preludial e exemplificadora. A técnica ou a arte, cujos dons e efeitos impõem persuasão imediata e garantida, é o território ideal para se isolarem as preciosas noções de particularidade e competência. $\mathrm{O}$ argumento técnico separa quem sabe de quem não sabe, e, sob seu patrocínio, a filosofia terá também requisitos, e os foros de um saber selecionado. A técnica, nos diálogos platônicos, não é uma exposição de saber técnico. Ela é pretextuada, alegorizada, de acordo com aquilo que se quer provar, além dela própria. Representa ou valoriza a dimensão manual e empírica do lógos, e, last but not least, é também uma abertura à urbana dimensão da vida. No Crátilo, contudo, há uma completa reversão. Não é o saber que se discute, a despeito dos esforços em contrário, despendidos por Sócrates. Discute-se a ciência da linguagem, que, vista como um ser autônomo, exige - não a alegorese - mas a própria técnica dos que estão a dialogar. A filosofia é, pois, testada fora de seus domínios. O Crátilo é, literalmente, um seminário técnico, que a filosofia defraudadamente busca encampar, e com razão observara certa vez Merleau-Ponty que o conhecimento da linguagem, até princípios deste século, nunca se elevara às alturas de uma filosofia "primeira". Ele é que estaria fadado, afinal, não a ser constituído, mas a constituir o seu filosofar primeiro, em nova ordem de apreensão do ser. Ora, sabemos o quanto essa tarefa dependeu da geração em que se inclui MerleauPonty, geração que fundamente foi cratiliana, e que, retornando aos estóicos, aos sofistas, aos pré-socráticos, restabeleceria a eminência do sentido como expressão primeira do existir. Tratou-se de um retorno aos enigmas do Crátilo. Pois é lá que as tensões entre a idéia e o sentido se formulam por primeira vez.

Provocado por Sócrates, Crátilo diz entender as palavras katà thumòn [= pela emoção] e recear, portanto, entendê-las katà noûn [= pela razão]. Os termos thymós e noûs patrocinam Crátilo e Sócrates. Desafortunadamente, falta, para a compreensão de tais palavras, uma elucidação semiológica, como as que Benveniste realizou em seu Vocabulário. A oposição entre "racional" e "emocional" é insuficiente. Pois thymós e noûs são modalidades de ação e de apreensão do mundo, comumente traduzidas por alma, entendimento, coragem, inteligência. Noûs é a faculdade de entender alguma coisa, de precisá-la na mente, de maneira a abs 
traí-la das demais. O noûs é o exercício do pensar, do verificar, do localizar: determina uma postura corporal do ato de prestar atenção. Minimal que seja, o exercício do noûs impõe uma reorientação, uma descontinuidade no gesto. Porém, pequena. Em Homero, essa palavra timbra a ostensividade de uma percepção. Thymós - ao contrário - é a inteligência momentânea e totalizadora. É, digamos, uma intuição, porém feita pelo corpo, pela alma, pelo espaço e pelas circunstâncias - tudo como evento uno e único. Da mesma forma que o noûs, o thymós também implica descontinuidade, com a diferença de que se trata agora de uma transformação humano-cosmológica. Enquanto o noûs separa e reforça no sujeito o entendimento do mundo, o thymós unifica e faz do sujeito um episódio do destino mundial. $\mathrm{O}$ noûs pode estar certo ou errado. Mas o thymós não. Ele, ao contrário, entranha inteligência do destino, em que alma, corpo e ação têm o mesmo peso. É inanalisável um momento de thymós, tal como os "agoras" do tempo em Agostinho. Reúne-se, no thymós, a um tempo, tudo, e isso é tudo que acontece nesse tempo. Entendida assim, a fusão de uma palavra com sua coisa, defendida por Crátilo, é irrespondível. É uma fusão perfeita, e tão completa, que toda justificação parecerá defraudada, quando não hilariante. Crátilo por certo entenderá que no curso da experiência as coisas todas são uma (o Uno de Heráclito), uma vez que nosso agora arrebata o inteiro cosmos, e não apenas esta nossa precária periferia, de onde o mundo legislamos como a um Outro. Ora, todas as coisas transformadas em uma ou, o que dará no mesmo, todas as palavras sendo seus objetos - é uma noção que pressupõe a semelhança. Não, obviamente, a semelhança de Sócrates, entre o mesmo e o distinto, claramente expostos ao olhar, mas a semelhança forçada, compulsória, que num só golpe nos torna filhos do universo. Petrarca falava num "ar de família", entre parentes não parecidos. E o termo semelhança vem do indoeuropeu sem*: significava "de golpe", "de uma vez apenas". As coisas quando apreendidas de golpe são familiares, e portanto semelhantes. Assim, em Crátilo (como em Charles Peirce), o termo gato é o próprio "gato". Por certo ambos sabiam que uma coisa é o nome, e outra coisa bem distinta é o animal. Porém, quando vividos num golpe, são a mesma coisa. Trata-se da semelhança interna ou pressuposta. Já a semelhança visível e exterior, essencial no socratismo (todo ele convergindo para a progressiva acuidade das sublimações visuais) é a responsável pelo abandono da questão da linguagem, diante da qual, por fim, Sócrates (e com ele Platão) se diz incompetente. De seu lado, a semelhança compulsória e discreta só é compreensível como determinação do tempo. A idéia aí é correlata à outra, à que acabamos de expor, e de acordo com a qual é o espaço, é o mundo inteiro que se põe agora no 
que falo ou no que faço. Com o passado ocorre a mesma coisa. Toda história do mundo concorre neste momento, neste presente, e de golpe, como uma forma aorística. Dá-se então uma espécie de violência virginal e necessária, entre o mundo e a alma, e a história ganha aí o seu maior sentido, que é o sentido natural, e a consciência ganha todo seu espaço. Assim, a reflexão pode escolher do que falar, pode inventar seus mitos. Ela mesma, porém, não é nenhuma escolha. Carrega o mundo, e indelevelmente vai tingida desse mundo, e pouco importa se com liberdade ela conteste o que carrega, ou sobretudo ela desminta que o carregue. Quem conhece os nomes também conhece as coisas. Por isso é que, do ponto-de-vista de Crátilo, será impossível mentir. Toda mentira é mentira, e essa é sua verdade. O verossímil da mentira, o parecer uma verdade pouco importa. A mentira pode não levar a ser algum. No entanto ela existe, põe seu ferrete no que diz, e, paradoxalmente, do ponto de vista da natureza, ela não poderá existir. Porque as mentiras são verdades, não no que dizem mas no fato de dizerem.

Daí vêm as conseqüências mais subtilizadas da ciência de Crátilo, vale dizer, existe um flatus vocis, um bavardage na linguagem, que não é a linguagem, e que poderá absorver todas as falsidades e derrisões. Aparentemente, esta polaridade é semelhante à de Sócrates, e que mais tarde Aristóteles iria desenvolver sob a forma falso-verdadeiro da lógica proposicional. Porém, a diferença é grande. De Aristóteles a Frege, a lógica preocupa-se com seus próprios ditames, que são formais. Ao contrário, a lógica de Crátilo é mais precisamente a que Deleuze chamaria lógica do sentido. Há, todavia, uma ponte entre ambas, e que os estóicos, seguindo a tradição de Heráclito, iriam revelar. Os que acompanham as intervenções de Crátilo podem haver reparado que estas não se abrem para intervenções temáticas, mas, ao contrário, para dúvidas, para subcondições, para pormenores, no sentido de condicionar o que se está dizendo. A tática de Crátilo é condicionalizante. Inferimos o que ele pode pensar a partir daquilo que ele recusa ou daquilo que não the caia bem, de maneira que de todas essas subcondições ou negativas vamos inferindo o que ele quer e o que não quer. Ora, já vimos que ele se mostra simpático à idéia da semelhança implícita. E já vimos que esta semelhança só pode ser postulada por uma crença radical que, de resto, recomenda o silêncio. Pois não podemos demonstrar que o gato e a palavra gato exteriormente se pareçam. Ora, os estóicos formularam um silogismo em que o bom senso, a semelhança externa, a compreensibilidade são dados de barato, e que, justamente, poderíamos chamar de silogismo da semelhança implícita (ou forçada, ou cega, etc.). Tratava-se, para eles, de reconhecer a convergência de eventos totalmente distintos, uma convergência por princípio, teste- 
munhada apenas como convergência, e que alguns deles, com certa graça, ilustravam com frases do tipo "se tu dizes uma carroça, uma carroça passa por tua boca". Do ponto de vista semântico, podemos julgar tal frase absurda, mas, vista formalmente, ela exibe um perfil condicional que não depende da verdade ou falsidade da informação semântica. A estrutura da condição será, portanto, fundamental ao signo, fundamental ao pensamento. A condição pode ser expressa em proposições do tipo "Se é o caso de A, também é o caso de B", onde A e B só podem ser entendidos como ocorrências ou como eventos, dado não haver aí nenhuma outra idéia reguladora. Portanto, A se parece com B, no sentido de que são afins, tal como a cobra e seu veneno, ou como o gato com o leite, ou a palavra com a coisa. É inútil explicar por que a cobra teria veneno, por que o gato beba o leite, por que a palavra indique a coisa. São relações existenciais, que a lógica incorpora a seu trabalho, sob a alegação de que a relação que exista entre duas coisas, de modo que uma seja condição da outra, é já, por princípio, uma explicação necessária e suficiente.

Isso nos permite entender outra das intuições de Crátilo, uma que, aparentemente, parece desdizer de Heráclito, a crença de que só existe uma palavra para cada coisa. Se é assim, como explicar a mudança, a desaparição e a invenção das palavras? Como arrazoar a "justeza natural", como não abandonar a tese de que o conhecimento das palavras é o conhecimento das coisas? Mais: se línguas têm palavras diversas para a mesma coisa, como a justeza natural será a mesma para bárbaros e gregos? Ora, o silogismo condicional (Se A, logo B) apenas reconhece que quando se dão certos eventos se dão obrigatoriamente outros. Se o mundo nos impõe uma impressão ao corpo, o mundo não pode estar mentindo. Cada impressão pede a palavra certa. Se empregamos outra, erramos contra a natureza, e sem dizer palavra alguma. E, desde que o mundo seja contínua diferença, os espaços e as línguas também serão diferentes, estarão noutros tempos, noutras relações com o homem. A anedota de Martinet, de que um português se escandalizava com os franceses a chamarem de fromage uma coisa que todos estavam a ver que era queijo - não é tão piadista assim. Tudo, entre França e Portugal, é diferente. A palavra certa, portanto, é a da hora.

\section{Notas}

* Professor Doutor de Língua e Literatura Grega do Curso de Graduação e do Programa de Pós-Graduação em Letras Clássicas da FFLCH-USP. 
1 “...des réflexions pénétrantes sur le langage e qui s'apparentent à certaines théories modernes" (Robin, 1967, p. 368).

2 "Platon appliquant le principe d'un genre littéraire alors à la mode, petite comédie philosophique dont Socrate sera le protagoniste obligé" (Robin, 1967, p. 369).

3 "Il [ = Cratyle] poussait à ses extrêmes conséquences la thèse héraclitéenne du devenir incessant de toutes choses, de la mobilité sans trêve qui emporte l'être et le fait toujours autre" (Robin, 1967, p. 368).

\section{REFERÊNCIAS BibLIOGRÁFICAS}

ROBIN, L. La pensée hellénique. Paris: PUF, 1967.

RODRIGUES, Antonio Medina. In defence of Cratylus.

ABSTRACT: The objective of this paper is to attempt an interpretation of Cratylus 's ideas in relation to the essence of language mostly those which can be inferred fom his denials of Socrates's propositions. KEYWORDS: inference; Heracleitus; similitude; syllogism; Socrates; conditional; modus ponens. 